\title{
E-Portfolio Assessment Design in Learning
}

\author{
Ambar Sri Lestari \\ IAIN (Islamic State Institute of Kendari) \\ ambarlstr@gmail.com
}

\begin{abstract}
This study examined the quality of learning outcomes; which can be assessed through a web-based portfolio assessment system. This student portfolios assessment includes reflective thinking skills through the collection of products that were made, in which to understand the knowledge acquired assessed by tests such as an essay, multiple choice, etc; which also covers writing skills through modules, and performance skills through the presentation. It was aimed to review the students' achievements and abilities obtained from their learning. The purpose of this study was (a) to design the portfolio assessment in the learning process, and (b) to assess the design of portfolio assessment in the learning process. Research methods and development were using ADDIE models, namely: analysis, design, development, implementation and evaluation. The results of this study were: a) the draft design of a portfolio assessment using Hypertext Preprocessor software (PHP) and Relational Database Management Systems (My SQL), and b) the results of the draft assessment portfolio declared that it was $90 \%$ eligible for use in the learning process through evaluation of the product, stated by a subject matter expert, media experts and teaching expert in which the collection of student work was done through blogs, you tube and slide share. The importance of this study was creating an assessment tool to assess student learning based on web-based portfolio.
\end{abstract}

Keywords-E-Portfolio, Assessment, PHP Software and My $S Q L$

\section{INTRODUCTION}

A portfolio is a collection of various evidence forms of learning outcomes assessments. In practical terms, the student portfolio for the assessment purpose is a summary of reports, papers, and other materials, along with a reflection on students' strengths and weaknesses [1]. A portfolio can complete classroom assessments; which integrated in various forms of assessment, namely the duty assessment, product assessment, test, project assessment, attitude assessment, and self-assessment.

There are three things that must be administered by an educator; the curriculum system, learning and assessment [2], students need to master those three mentioned things. Moreover, it was proven that the process of making the portfolio as a learning tool promoted the increasing of students' academic achievement, achievement motivation, critical thinking, self-learning, self-confident, and creative thinking [3]. Lecturers should know which competence or performance of students that required to be assessed, for example: understanding the knowledge; knowing the application of knowledge; and the assessment of performance in daily life.

An e-portfolio without any reflection was merely a media file documents, summaries of electronic or digital collection. Therefore, we could create portfolios focus on adding a proper reflection and feedback, such as learning journals, self-assessment, peer assessment and feedback into the web-based portfolio assessment [4].

Former learning style had already used e-learning for students by applying the knowledge assessment test through essay or multiple choice. Now e-portfolio is required to complete the student performance assessment. With this kind of background, the necessity to design e-portfolio to be integrated with the classroom assessment became inevitable. The process can be done in various forms of assessment.

\section{THEORETICAL FRAMEWORK}

Electronic portfolio, usually known as e-portfolio, is a collection of digital artifacts representing individuals, groups, communities, organizations, or institutions [5]. Teaching is a conscious effort to provide activities and learning experiences for students which is designed according to the needs and abilities of different levels [6]. Therefore, learning needs to be designed in order to provide services to students in order to achieve the level of mental and physical development to the fullest to fulfill their needs, instructional design should be based on learning theory, systems analysis, research and technological development [7].

The developed web-based portfolio scoring system includes goals setting, writing reflections, upload jobs and demonstrations, self-assessment, assessment friend, teacher appraisal and feedback, etc. [8]. The steps in the process for the portfolio assessment [9], are:

1. Lecturers and students must clearly identify the contents of the portfolio, which is in a form of examples of student work, reflection, observation and minutes of meeting.

2. Lecturer should develop evaluation procedures to track the portfolio contents and to rank the portfolios

3. Lecturers need to hold a meeting, the formal and informal, where students could review their work and discuss their progress.

The portfolio makes the students reflect themselves to express their learning experience, and it is an effective form of assessment to encourage them to be able to assess the capabilities which can not be assessed with traditional assessment. For example, the capability to think critically, 
communicate, and collaborate [10]. This statement shows that the assessment of e-portfolios can be used to encourage reflection and growth in generic skills of students.

E-Portfolio applications were developed by the open source platform, namely PHP and MySQL, as its database [11]. MySQL is a multi-functional and multi-user database management system software (DBMS). MySQL is a Relational Database Management System (RDBMS); which distributed for free under the GPL (General Public License) [12]. Portfolio design using Entity Relationship Diagram (ERD) is a technique used to model the data needs of the organization, usually with system analyst in the stage of the needs analysis of system development project [13]. And Data Flow Diagrams (DFD) is used as a graphical representation of the system, which describes the inputs, processes and outputs of the system [14]. PHP as the abbreviation of Hypertext Preprocessor is an open source language programming server-side web. PHP script used to create dynamic websites open source. PHP code is open public and free of charge, which allows the developers to make improvements and development. PHP also comes with other support from Oracle, SQL, and others. [15]

\section{REASEARCH METHODS}

This research is categorized as a research \& development ( $\mathrm{R} \& \mathrm{D})$, which the method was used to produce a specific product and test the effectiveness of the product [16]. The procedures in the development of eportfolios using ADDIE model [17] as the abbreviation of: (1) Analysis, (2) Design, (3) Development, (4) Implementation and (5) Evaluation.

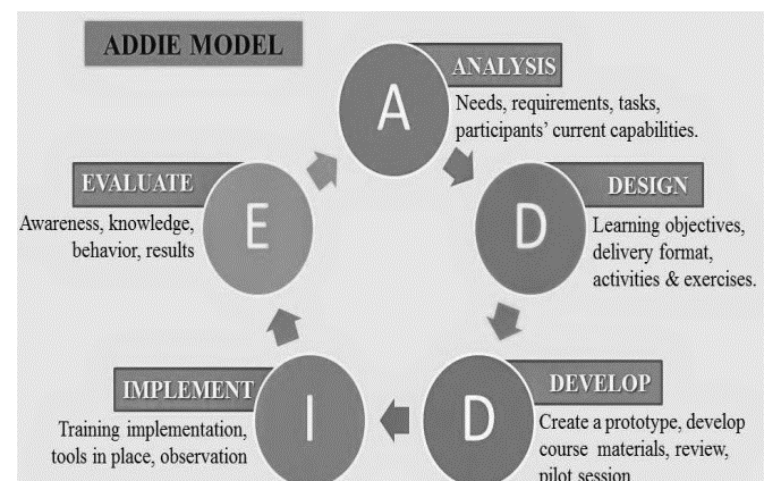

Figure1. Instructional System Design (Dick and Carry)

The first stage covers need analysis, reporting requirements, tasks, and the ability of the participants at this time; the second stage covers the goal, instructional design, and training activities; the third step covers developing a prototype, study materials, review; the fourth stage covers the implementation, and the fifth stage covers evaluating the knowledge, attitudes and outcomes.

\section{RESEARCH FINDINGS AND DISCUSSION}

\section{A. RESEARCH FINDINGS}

The stages in a study conducted with ADDIE (Analysis, Design, Development, Implementation, and Evaluation) model are as follow:

1. Analysis

The analysis is the process of determining what to do during the need assessments, problems identification, and tasks analysis performance.

TABLE I. Needs Analysis

\begin{tabular}{|c|c|c|}
\hline Needs Analysis & Problems Identification & Tasks Analysis \\
\hline $\begin{array}{l}\text { Context } \\
\text { Description }\end{array}$ & $\begin{array}{l}\text { A web-based e-portfolio } \\
\text { needs to be developed } \\
\text { Authentic } \\
\text { assessment/integrated } \\
\text { needed } \\
\text { Learning Assessment still in } \\
\text { a form of a test such as } \\
\text { essays and multiple choice }\end{array}$ & $\begin{array}{l}\text { Using e-portfolios } \\
\text { such as performance } \\
\text { evaluation, product } \\
\text { assessment, } \\
\text { assignments, tests, } \\
\text { attitude assessment, } \\
\text { self-assessment and } \\
\text { portfolio } \\
\text { assessment. }\end{array}$ \\
\hline $\begin{array}{l}\text { Analysis and } \\
\text { Reflection }\end{array}$ & $\begin{array}{l}\text { Need to be developed for } \\
\text { certain assessments } \\
\text { Teaching strategies are } \\
\text { required }\end{array}$ & $\begin{array}{l}\text { Writing a self } \\
\text { reflection } \\
\text { Documenting and } \\
\text { analyzing student } \\
\text { learning outcomes }\end{array}$ \\
\hline $\begin{array}{l}\text { Conclusions and } \\
\text { Planning }\end{array}$ & $\begin{array}{lll}\text { Planning } \\
\text { evaluation }\end{array}$ & $\begin{array}{l}\text { Portfolio will } \\
\text { support teaching } \\
\text { more effectively }\end{array}$ \\
\hline
\end{tabular}

The reflective needs analysis includes three components: 1) context description, 2) analysis and reflection, and 3) conclusions and planning [18]. Context description describes the responsibilities, objectives, evidence of activities and result achievement; follow by the process of analysis and reflection to analyze the evidence of activities, and the final conclusions and planning; which covers teaching dynamically as a teaching tool patch-up. 


\section{E-portfolio Design}

The systematic e-portfolios design is implemented in the learning assessment design as follows:

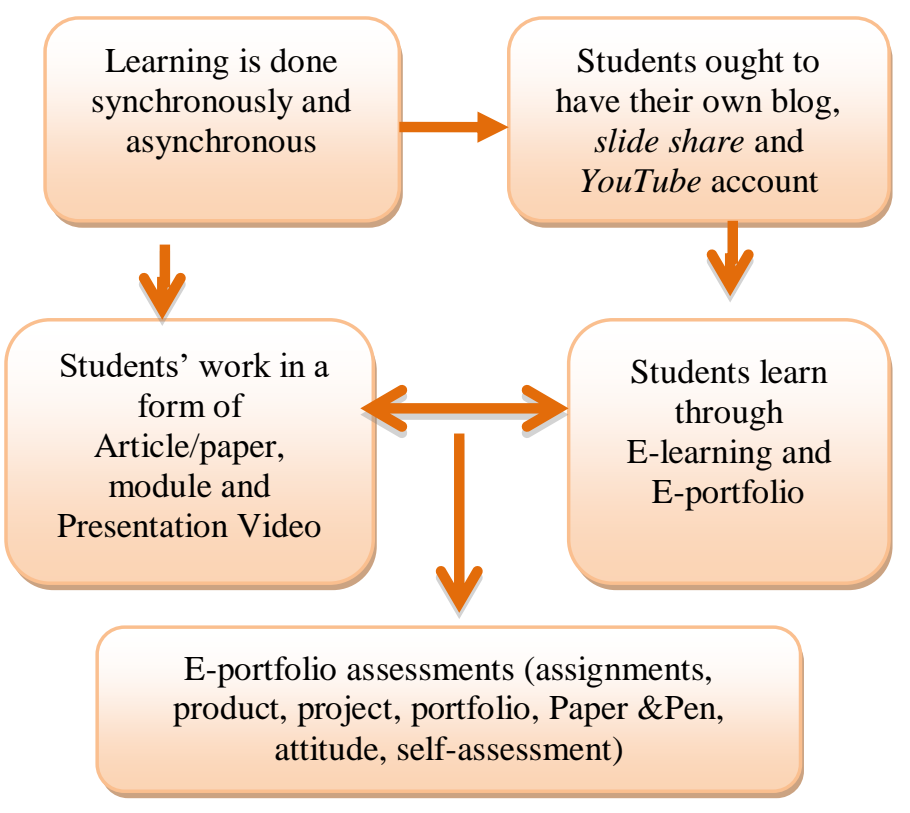

Figure 2. E-Portfolio Design

The learning method was done in a form of face to face and outside the classroom, learning not merely includes the tests and examinations, but also a variety of products and learning demonstration; namely, portfolios, exhibitions, performances, presentations, simulations, multimedia projects, and a variety of other outcomes such as paper, modules and visual presentation (see Figure 2. E-portfolio Design).

\section{E-portfolio Development}

To develop an e-portfolio system, XAMPP support system is used. It is an open web server containing MySQL and PHP in one package, thus making it easy to install and use. XAMPP is used to create a local server or so-called localhost that can run on multiple operating systems such as Microsoft Windows, Linux, etc.

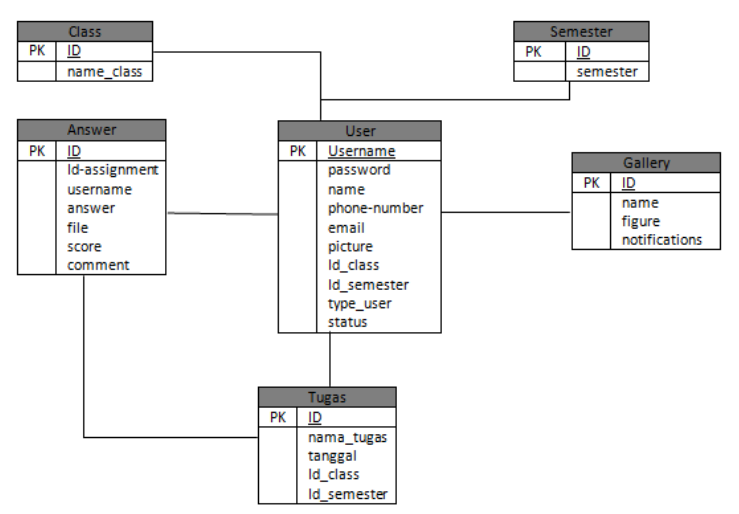

Figure 3. Entity Relationship E-Portfolio Diagram

Entity Relationship Diagram is a model describing the relationship between the data in the database based on the object notation and symbols (see Figure 3 Entity Relationship E-portfolio Diagram).

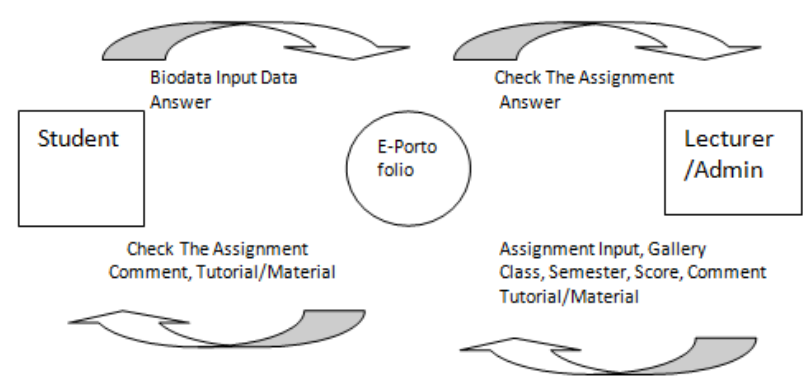

Figure 4. Data Flow E-Portfolio Diagram

Data Flow Diagram is a notation symbol diagram to describe the data flow system. This stage is important because it determines the shape of the system to be built. The system is constructed using the entity relationship diagrams and data flow diagrams (see Figure 4 Data Flow E-portfolios Diagram).

\section{E-portfolio Implementation}

The developed e-portfolios implementation can be seen inhttp://www.ambarsrilestari.com.

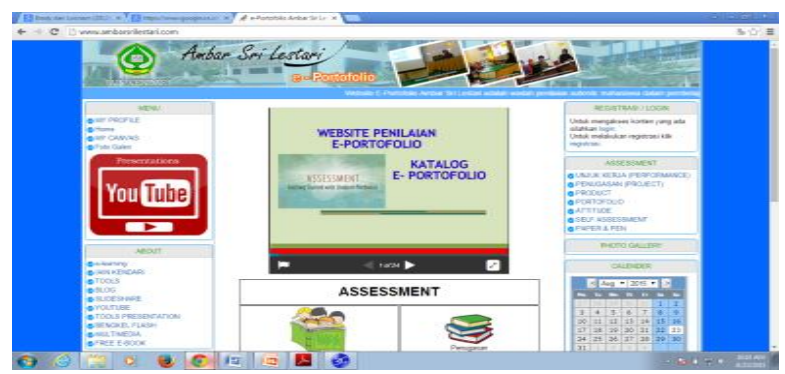

Figure 5. E-Portfolio Interface

E-portfolios have three parts to upload students' work, such as: blogs for uploading paper slide share to upload module and YouTube to upload presentation (see Figure 5 Eportfolios Interface). 


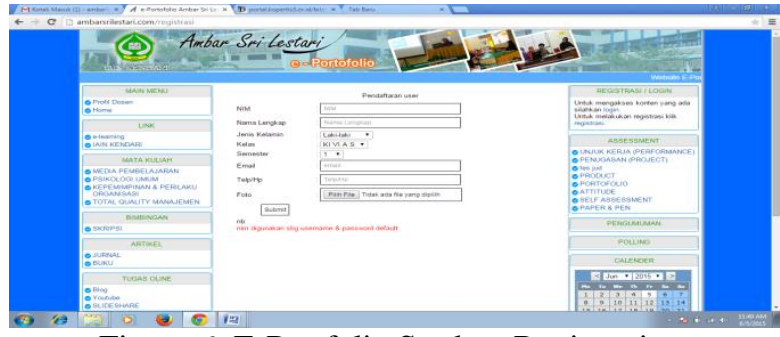

Figure 6. E-Portfolio Student Registration

Students are asked to complete the registration form, and then the lecturer will enable their status thus they can upload their task by filling in their identity as a user (see Figure 6. E-portfolio Student Registration).

TABLE 2

Overall Assessment By Media Experts, Materials And Design Teaching

\begin{tabular}{|c|c|c|c|c|}
\hline No & Criteria & $\begin{array}{c}\text { Each Aspect } \\
\text { Score }\end{array}$ & Average & Percentage \\
\hline 1 & Materials & 34 & 34 & $97 \%$ \\
\hline 2 & Media & 24 & 24 & $96 \%$ \\
\hline 3 & $\begin{array}{c}\text { Design } \\
\text { Teaching }\end{array}$ & 19 & 19 & $95 \%$ \\
\hline \multicolumn{2}{|r|}{ Total } & 77 & 77 & $97 \%$ \\
\hline
\end{tabular}

Based on the results of the evaluation by experts and field trials of e-portfolio quality assessment, the conclusions obtained based on the results of experts' assessment this activity was included in the excellent category with a total score of 97 percent.

The evaluation results of the individual tests, experiments small groups, and field tests are as follows:

\section{E-portfolio Evaluation}

Portfolio evaluation is done through media expert, expert teaching materials and design expert.

TABLE 3.

INDIVIDUAL RESUlTS, SMALL GROUP AND FIELD TEST

\begin{tabular}{|l|l|l|l|l|}
\hline $\begin{array}{l}\text { Total } \\
\text { item } \\
\text { sample }\end{array}$ & Category & $\begin{array}{l}\text { Ran } \\
\mathrm{k}\end{array}$ & $\begin{array}{l}\text { Empirical } \\
\text { Score/Ideal } \\
100 \%\end{array}$ & $\begin{array}{l}\text { Empirical } \\
\text { Score/Ideal } \\
100 \%\end{array}$ \\
\hline 550 & Very good & 5 & $2750 / 5950$ & $42 \%$ \\
\hline 325 & Good & 4 & $1300 / 5950$ & $32 \%$ \\
\hline 315 & Average & 3 & $945 / 5950$ & $10 \%$ \\
\hline 0 & Poor & 2 & 0 & 0 \\
\hline 0 & Very Poor & 1 & 0 & 0 \\
\hline & & & $4995 / 5950$ & $83 \%$ \\
\hline
\end{tabular}

The results of the individual tests is $85 \%$, a small group test is $82 \%$ and the field test was $85 \%$ as for the total was $84 \%$; which represents good qualifications in the layout, simple look and categorized as an easy-to-use media, as well as the clarity of the media instructions.

Below is the students' response evaluation:
TABLE 4.

Students' Response Result

\begin{tabular}{|l|l|c|}
\hline No & Criteria & Empirical Score/Ideal x 100\% \\
\hline 1 & Individual Test & $85 \%$ \\
& & \\
\hline 2 & Small Group Sample & $82 \%$ \\
\hline 3 & Field Test & $85 \%$ \\
\hline \multicolumn{2}{|c|}{ Total } & $84 \%$ \\
\hline
\end{tabular}

Students' response to use e-portfolio assessment reached a positive response with an average $83 \%$ based on the students' opinion and were categorized as very good/decent as well as provide a new experience for students.

\section{B. DISCUSSION}

A portfolio is a collection of evidence or information about the student or group of students; which show academic progress, potential, skills, and attitudes. Thus, portfolio assessment is gathering information about students through some students work evidence in an ongoing basis. Through the portfolio implementation, the acquired information holistically was gained on the student's abilities, namely, cognitive, affective, and psychomotor. A portfolio is a systematic collection of student work related material that describes the students' activities as well as their achievement in one or more subjects.

A study suggested [19] that by adopting e-portfolio into the curriculum and providing the e-portfolio structure development of certain courses or study, it is proven that there were increasing concerns for the level of ability in self-learners so that learners are encouraged to further develop their capabilities. This suggests that the portfolio assessment can encourage the growth of awareness and motivation to develop.

Other studies [20] argued that the implications of portfolio assessment must involve students' reflections, with a view to enable the students to review their own learning process. It said that portfolio assessment also allows students to identify most suited learning methods to reflect on their experiences and thus promotes the students' learning abilities.

The difference between this study with other portfolio research lies in the fact that this e-portfolios study were created and designed in a very simple and easy-to-use for students. Furthermore, the portfolio complemented the previous e-learning assessment. In addition, the contents of the e-portfolio assessment had three parts, namely, blogs, slide share and YouTube of the student's work.

Reflection involved introspection and learner comments. Deeper reflection would be really helpful to the learning process [21]. Therefore, it is acceptable that the content of reflection has given a positive effect significantly on the learning outcomes, which are consistent with results from other studies that might focus on a broad range of 
disciplines or subjects. In attitude, the use of portfolio assessment can strengthen students' motive to learn [22]. In the result of learning, reflective journal writing can improve science literacy for services [23].

Portfolio-based assessment is an attempt to obtain a variety of information on a regular, continuous and about the process and the growth result as well as the development of knowledge, attitudes, and skills of learners who come from records and documentation of their learning experience [24]. Through the implementation of the portfolio assessment, the results and the process of learning will be meaningful. The characteristics of authentic assessment are: (1) the assessment carried out by involving learners realistically in assessing their own achievements, (2) an assessment based on performance, realistic, and in accordance with the learning, (3) ... information or data collected from various sources, through various methods [25]. The policies contained in the competency-based learning also found: (1) assessed only the competence (not the others), and (2) by: (a) a written test, (b) work, (c) the provision of duty, (d) assessment of the project, (e) the product assessment, (f), a portfolio assessment, and (3) the type of assessment should allow the best opportunity for students to show what they know and understand, and demonstrate their abilities, which began to be introduced in the portfolio assessment [26].

The results were not merely determined by the learning assessment criteria, as what has been done by having a test in which choices would only be seen from the cognitive aspects while learners are seen as unique individuals in which the value of each individual should be seen as an integral part of these three aspects; namely cognitive, affective and psychomotor. Thus, the assessment will be thorough and not fractional.

\section{CONCLUSION}

1. The draft of e-portfolio assessment using PHP and MySQL open source software and the development of e-portfolios using analysis, design, development, implementation and evaluation (ADDIE) model from Dick and Carry. The results of materials expert assessment, media and instructional design were on the achievement level of $90 \%$, which means that the product categorized as very good / feasible to use in learning. While during individual testing, small group test and a field test resulted with a total value of $84 \%$, which means that the assessment of e-portfolios categorized as very good/feasible to be used in learning.

2. Students' response using portfolio assessment was positive on average by $83 \%$ and stated that it can provide new experiences for learning.

\section{Acknowledgement}

Thanks to the State Islamic Institute of Kendari's research institutions and public service whose offered space to the development of research in the field of teaching.

\section{REFERENCES}

[1] Davis MH, Friedman Ben-David M, Harden RM,Howie J, Ker J, McGhee C, Pippard MJ, Snadden D. Portfolio assessment in medical students' final examinations.Med Teach23:357-366, 2001

[2] Surapranata, Sumarna dan Muhammad Hatta. " Portofolio Assessment : Implementation of Curikulum 2004. Bandung: Remaja Rosdakarya. Press. 2004.p.1.

[3] Marianne, T., Denise, P. Learning portfolio models in health regulatory colleges of Ontario, Canada. Journal of Continuing Education in the Health Professions, 30 (1), 57-64,2010.

[4] Barrett, H. C. Electronic Portfolios as Digital Stories of Deep Learning.Retrieved August 18, 2009, from http://electronicportfolios.com/digistory/epstory.html.2004.

[5] Lorenzo, G. \& Ittelson, J. An Overview of E-Portfolio. Educause Learning Initiative. Procedia - Social and Behavioral Sciences. Volume 176, 20 February 2015, Pages 3-13.

[6] Danielle S. McNamara, Ed., Reading Comprehension Strategies: Theories, Interventions, and Technologies. New York: Guilford Press, 61, 2005.

[7] Morrison, Designing Effective Instruction, $5^{\text {th }}$. Indiana: John Wiley and Son, Inc.,6, 2007

[8] Chang, C. C. Enhancing Self-Perceived Effects Using Web-Based Portfolio Assessment. Computers in Human Behavior, 24(3), 17531771.2008.

[9] Venn, J.J.Assessing Students With Special Needs (2nd ed) .Upper Saddle River, NJ: Merrill. 530-531, 2000.

[10] Sweat-Guy, R. \& Buzzetto-More, N. A. A Comparative Analysis of Common E-Portfolio Features and Available Platforms. http://proceedings.informingscience.org.2006. Access on $26 \mathrm{Mei}$ 2015

[11] Purwanto, Yudhi. Web programming with PHP: Short exactly clear. Jakarta: Elex Media Komputindo.2001.

[12] Sidik, Bertha. For MySQL User, Administrator and Application Developer web. Bandung: Informatics Bandung.2003.

[13] Brady, M.,\& Loonam, J. Exploring The Use of Entity-Relationship Diagramming as a Technique to Support Grounded Theory Inquiry. Bradford: Emerald Group Publishing. 25, 2010.

[14] E. Kenneth Kendall and Kendall E Julie. Analysis and Design System. Fourth Edition. Bandung: PT Index. 265, 2006.

[15] Anhar. Free Master PHP \& MySQL Autodidact. Jakarta: PT.TransMedia. 3, 2010.

[16] Sugiyono. Qualitative and Quantitative Research Methods R \& D Bandung. Alfabeta.2008.

[17] Dick, W., And Carey, L. The Systematic Design Of Instruction.Pearson Education, 8th ed. 2014

[18] Campbell, D.M.,Cignetti, P.B., Melenyzer, B.J., Nettles, D.H.,\& Wyman, R.M. How to Develop A Professional Portfolio: A Manual For Teachers (2 ed). Boston, MA: Allyn \& Bacon.2001.

[19] Cranney, J., Kofod, M., Huon, G., Jensen, L., Levin, K., McAlpine I., Scoufis, M. And Whitaker, N. Portfolio Tools: Learning and Teaching Strategies to Facilitate Development of Graduate Attributes. UniServe Science Blended Learning Symposium Proceedings. 2005.

[20] Chang, C. C. Enhancing Self-Perceived Effects Using Web-Based Portfolio Assessment. Computers in Human Behavior, 24(3), 17531771.2008.

[21] Masui, C., \& De Corte, E. Learning to reflect and to attribute constructively as basic components of self-regulated learning. British Journal of Educational Psychology, 75(3), 351-372.2005.

[22] McAlpine, D. (2000). Assessment and the gifted. Tall Poppies, 25(1) Retrieved August 30, 2009, from http://www.tki.org.nz/r/gifted/pedagogy/portfolio e.php

[23] Gibson, H., Bernhard, J., Kroof, A., Ramirez, M., \& Van Strat, G. Enhancing the science literacy of preservice teachers through the use of reflective journals.Paper presented at the Annual Meeting of the National Association for Research in Science Teaching, St. Louis, Michigan. 2001.

[24] Dasim Budimansyah. Learning and Assessment Model Portofolio.Bandung:PT. Grasindo, 3, 2002.

[25] Ministry of Education. Curriculum 2004: Special Guidelines For Development Portfolio Assessment, 71,2003.

[26] Surapranata and Hatta. Portfolio Assessment: Implementation of Curriculum 2004. Bandung: PT Youth Rosdakarya, 18-21, 2006. 